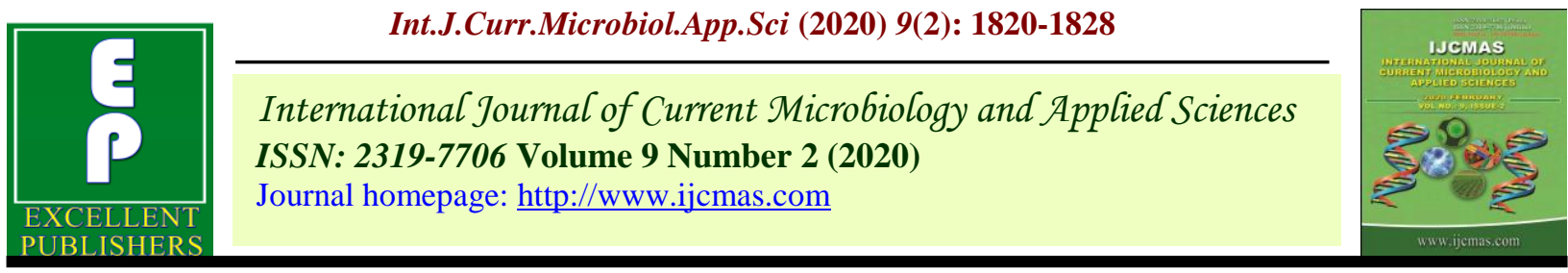

Original Research Article

https://doi.org/10.20546/ijcmas.2020.902.208

\title{
Optimization of process Parameter for the Production of Dehydrated Garlic Slices by using Freeze-Thaw Convective Drying Technique
}

\author{
M. H. Gajabe*, S. U. Khodke, P. G. More and Nilza Othezes \\ Department of Agricultural Process Engineering, CAET, VNMKV, \\ Parbhani - 431402 (M.S.), India \\ *Corresponding author
}

\begin{tabular}{|l|}
\hline Key w or d s \\
$\begin{array}{l}\text { Dehydrated garlic } \\
\text { slices, Freeze-thaw } \\
\text { convective drying, } \\
\text { Response Surface } \\
\text { Methodology }\end{array}$ \\
\hline Article Info \\
\hline $\begin{array}{l}\text { Accepted: } \\
\text { 08 January 2020 } \\
\text { Available Online: } \\
\text { 10 February 2020 }\end{array}$ \\
\hline \hline
\end{tabular}

\section{A B S T R A C T}

Freeze-thaw convection drying is an innovative technique that could dramatically reduce processing times for many foods. Optimization of the process for the production of dehydrated garlic slices by using freeze-thaw convective drying technique was performed by using Box-Behnken Design. The effect of freezing temperature $\left(-5,-15\right.$ and $\left.-25^{\circ} \mathrm{C}\right)$, thawing temperature $(1$, 15 and $\left.30^{\circ} \mathrm{C}\right)$ and drying air temperature $\left(50^{\circ}, 60^{\circ}\right.$ and $\left.70^{\circ} \mathrm{C}\right)$ was investigated on quality attributes of freeze thaw dehydrated garlic slices, in terms of colour (L-value), hardness (HD), rehydration ratio (RR) and shrinkage ratio. An analysis of variance (ANOVA) revealed the process variables, viz: freezing temperature, thawing temperature and drying temperature had a significantly positive impact on quality attributes of freeze thaw dehydrated garlic slices. The optimum product qualities of freeze-thaw dehydrated garlic slices in terms of colour (L-value 59.55), hardness (2395 g), maximum rehydration ratio $(2.854 \%)$ and minimum shrinkage ratio $(0.455 \%)$ obtained by computer generated response surfaces and contour plot interpretation were: $-25^{\circ} \mathrm{C}$ freezing temperature, $5^{\circ} \mathrm{C}$ of thawing temperature and $60^{\circ} \mathrm{C}$ drying temperature.

\section{Introduction}

Garlic (Allium sativumL.), belongs to the Liliaceae family, is a common food spice, used widely in many parts of the world. Garlic is one of the important commodities in the Indian kitchens which add specific taste and flavor to the food preparation. It is an important allium spice which strong source of phenolic compounds and provides several health benefits with its medicinal properties.
Garlic is known as medicinal plants used to cure different diseases in human from ancient time. Garlic can rightfully be called one of the nature's wonderful plants with healing power. Allicin is an unstable compound that is present in fresh garlic after it's been cut or crushed. It can be inhibit and kill bacteria, fungi, lower (blood pressure, blood cholesterol and blood sugar), prevent blood coating, contain anti-tumor properties (Gebreyohannes, 2013). The moisture content 
of fresh harvested garlic is approximately $61.82 \%$ (wet basis) (Ambrose \& Sreenarayanan, 1998).

Garlic processing involves bulb breaking, peeling, dehydration, grinding, packing and storage. Garlic can be processed into different value added products like minimally processed ready to used peeled garlic cloves, dehydrated flakes, power, paste, pickles, oil etc.

Hot air drying is a common way used to dehydrated garlic slices, the quality of dried product is usually significantly lower than fresh ones. Case-hardening is another defect found in hot air dried product. Garlic is very sensible to temperature; choosing right drying method can be the key for successful operation and to obtain high-end quality product. (Prachayawarakorn et al., 2006). Dehydration is one of the best method for garlic preservation. Dehydrated garlic has great commercial value and is used as a spice or standard ingredient in prepared foods and formulations. Also, it extends the shelf-life with sensorial characteristics similar to those of fresh products and a high nutritive value.

Freeze-thaw convective drying is a combo processing technique and it is commercially applicable. During freezing the formation of small ice crystals during nucleation and that these may cause less damage than the large ice crystals formed during slow freezing and thus improve the quality of frozen foods. No references concerning freeze-thaw convective drying process of garlic slices were found in the previous literature. Freezing and thawing process before drying may retain the garlic physical properties considering this concept. In the present investigation it was decided to focus on standardized the process for production of dehydrated garlic slices using freeze-thaw convective drying.

\section{Materials and Methods}

\section{Sample preparation and Experimental procedure}

The selected variety (G-41) of garlic was thoroughly cleaned with tissue paper to remove the dirt or dust particles attached to the surface of garlic cloves. The garlic were peeled and cut using a sharp stainless steel knife into circular slices of approximate $5 \mathrm{~mm}$ $( \pm 1 \mathrm{~mm})$ thickness.

The initial moisture content of raw garlic slices was determined by using oven method (AOAC, 2000). Garlic slices were freeze at different levels $\left(-5,-15\right.$ and $\left.-25{ }^{\circ} \mathrm{C}\right)$ in deep freeze and then thawed at 1,15 and $30^{\circ} \mathrm{C}$ temperature level. Freeze-thawed garlic slices were then dried at different temperature level at 50,60 and $70^{\circ} \mathrm{C}$ using a mechanical tray dryer.

\section{Quality evaluation of freeze-thaw dehydrated garlic slices}

The quality of freeze-thaw dehydrated garlic slices, were evaluated by determining the hardness, colour, rehydration ratio and shrinkage ratio adopting the standard procedures discussed below.

\section{Texture analysis}

The texture of the dried garlic slices was evaluated by using a Texture Analyzer (TAXT2i) employing the method suggested by (Nouriyan et al., 2003). A dried garlic slice was placed on platform. A compressive force was applied to the sample by a $2 \mathrm{~mm}$ diameter cylindrical probe at a constant speed of 0.5 $\mathrm{mm} / \mathrm{s}$. The maximum compressive force at rupture of each sample considered as hardness of garlic slice. The test was replicated five times and the average value was taken. 


\section{Colour}

The colour value of the dried garlic slices was measured in terms of $\mathrm{L}$ (the degree of the lightness), using a Hunter Lab Color Analyzer- Labscan-2 (Hunter Associates Laboratory, Inc. Virginia, USA).

\section{Rehydration ratio}

Rehydration ratio (RR) was evaluated by soaking known weight (10 g) of each sample in sufficient volume of water in a glass beaker (approximately 30 times the weight of sample) at $95^{\circ} \mathrm{C}$ for 20 minutes. In order to minimize the leaching losses, water bath was used for maintaining the defined temperature (Rangana 1995) After soaking, the excess water was removed with the help of filter paper and samples were weighed.). Rehydration ratio (RR) of the samples was computed as follows:

$$
\mathrm{RR}=\frac{\mathrm{wr}}{\mathrm{wd}}
$$

Where, $\mathrm{Wr}=$ Drained weight of rehydrated sample, $\mathrm{g}$

$\mathrm{Wd}=$ Weight of dried sample used for rehydration, $\mathrm{g}$

\section{Shrinkage ratio}

The shrinkage ratio (SR) of dried sample was measured by toluene displacement method. Shrinkage ratio was computed as the percentage change from the initial apparent volume (Rangana 1995).

$$
S R=\frac{V_{r}}{V_{0}}
$$

Where, $\mathrm{Vr}=$ Volume displaced by rehydrated sample, $\mathrm{ml}$

$\mathrm{V} 0=$ Volume displaced by fresh sample, $\mathrm{ml}$

\section{Experimental design and statistical analysis}

Response Surface Methodology (RSM) with Box and Behnken design was used to estimate the main effects of Freeze Thaw Dehydration process on colour (L-value), hardness, shrinkage ratio and rehydration ratio in garlic slices. This design was used with independent variables viz. freezing temperature $(\mathrm{F})$, thawing temperature (T), and drying temperature (D) (Table 1). The Box and Behnken Design of three variables and the three levels including 17 trials formed by 5 central points were used (Design Expert version 11.). It is assumed that the mathematical function $\mathrm{fk}(\mathrm{k}=1,2,3, \ldots . . \mathrm{n})$, exists for each response variable, Yk in terms of the processing factors, ri $(\mathrm{i}=1,2,3, \ldots \ldots \mathrm{m})$, such as

$$
Y_{k}=f_{k}\left(r_{1}, r_{2}, r_{3}, \ldots r_{i}\right)
$$

The exact mathematical representation of the function (f) is either unknown or extremely complex. However, second order polynomial equation of the following form was assumed to relate the response, $\mathrm{Yk}$ and the factors, ri

$$
\mathrm{Y}_{\mathrm{k}}=\beta_{k o}+\sum_{i=1}^{i=3} \beta_{\mathrm{ki}} \mathrm{x}_{\mathrm{i}}+\sum_{i=1}^{i=3} \beta_{\mathrm{kii}} \mathrm{x}_{\mathrm{i}}{ }^{2}+\sum_{\mathrm{i}=1}^{\mathrm{i}=2} \sum_{j=i+1}^{j=3} \beta_{\mathrm{kj}} \mathrm{x}_{\mathrm{i}} \mathrm{x}_{\mathrm{j}} \ldots(4)
$$

where, $\beta \mathrm{ko}, \beta \mathrm{ki}, \beta \mathrm{kii}$ and $\beta \mathrm{kij}$ are constant coefficients and $\mathrm{xi}$, the coded independent variables are linearly related to $\mathrm{F}, \mathrm{T}$ and $\mathrm{D}$. In practice, the levels of independent variables change from one application to another.

\section{Results and Discussion}

Effect of process variable on colour ( $\mathrm{L}$ value) of freeze-thaw dehydrated garlic slices

The values of variation in colour (L-value) of dehydrated garlic slices were studied by 
changing freezing temperature, thawing temperature and drying temperature in experimental studies and it is presented in Table 2. A variation in colour was observed for different experimental combination i.e 48.69 to $59.56 \%$. A second order polynomial equation (4) was fitted with the experimental data.

The quadratic model was fitted with the experimental data and the statistical significance for linear, quadratic and interaction terms were computed for colour as presented in Table 3. The $\mathrm{R}^{2}$ value was computed by least square technique and it was found to be 0.9757 for colour, which shows a good fit of model with the data. The model $\mathrm{F}$ value of 31.21 for colour implies that the model is significant $(\mathrm{P}<0.0001)$.

The $\mathrm{F}$ value of lack of fit was non-significant which indicated that the developed model was adequate for predicting the colour during production of freeze-thaw dehydrated garlic slices..

The regression equation describing the effect of process variables on colour in terms of coded values of variable is given in Eq. (5). The data for colour was analysed by stepwise regression method where factors with $\mathrm{F}$ values less than one were rejected as suggested by Snedecor and Cochran (1967).

$$
\begin{aligned}
& \mathrm{CL}=56.54-1.39 \mathrm{x}_{1}-1.27 \mathrm{x}_{2}-2.53 x_{3}+0.7500 \mathrm{x}_{1} \mathrm{x}_{3} \\
& +1.16 \mathrm{x}_{2} \mathrm{x}_{3}+1.738 \mathrm{x}_{1}^{2}-1.34 \mathrm{x}_{2}^{2}-4.31 \mathrm{x}_{3}^{2} \ldots(5)
\end{aligned}
$$

The effect of individual variables and their interactions on colour are explained with the help of coefficients of Eq. 5. It was observed that the freezing temperature contributed maximum for CL, followed by thawing temperature and drying temperature. The presence of quadratic terms of the variables in Eq. 5 indicated curvilinear nature of the response surface (i.e. observed CL).
However, the negative coefficient for process variables of quadratic terms reveals that an excessive increase in the levels of these variables resulted insignificant decrease in colour Rise in thawing temperature cause more amount of drip loss resulting in softening of tissue and loss in firmness (Fuchigami 1994) which further reflects in deterioration of quality in terms of colour after dehydration. It was observed that the colour (L-value) slightly increased and then decreased gradually as drying temperature increases.

\section{Effect of process variable on hardness of freeze-thaw dehydrated garlic slices}

The experimental values of hardness during production of freeze-thaw dehydrated garlic slices by varying the process parameters is 2384 to $2714 \mathrm{~g}$. Table 3 shows that the effect of all process variables was significant at linear, quadratic and interaction level for hardness. The $\mathrm{R}^{2}$ value was found to be 0.9860 for hardness, which shows a good fit of model with the data. The model $\mathrm{F}$ value of 13.36 for hardness implies that the model is significant $(\mathrm{P}<0.0001)$. The $\mathrm{F}$ value of lack of fit was non-significant which indicated that the developed model was adequate for predicting the hardness during the production freeze-thaw dehydrated garlic slices.

A second order polynomial equation eq. (4) was fitted with the experimental data. The regression equation describing the effects of process variables on hardness in terms of coded values of variable is given in Eq. (6). The data for hardness were analysed by stepwise regression method where factors with F-values less than one were rejected as suggested by Snedecor and Cochran (1967).

$$
\begin{aligned}
& \mathrm{H}=2453.57+63.65 x_{1}+72 x_{2}+1.9286 .46 x_{3} \\
& +30.53 x_{1} x_{2}+2.25 x_{1} x_{3}+0.3575 x_{1} x_{3}-9.33 x_{2} x_{3}-5.98 x_{1}^{2}
\end{aligned}
$$


$+92.90 x_{2}^{2}+118.03 x_{3}^{2}$

Coefficients of Eq. 6 were explained the effect of individual variables and their interactions on hardness. It was observed that the thawing temperature contributed maximum for hardness, followed by freezing temperature and drying temperature. Excessive increase in the levels of these variables resulted in significant increase in hardness, $\mathrm{g}$ and it is reflected by negative coefficients for the quadratic and interaction terms.

It was observed that as freezing temperature increased hardness of the product decreased this may due to formation of bigger ice crystal during freezing at higher freezing temperature.

Hardness increased with an increase in thawing temperature this might be due to fact that, rapid rate of thawing might have ruptured the cell structure resulting in case of hardening. Similar results were found for freeze-thaw dehydration technology for production of instant potato cubes (Khodke 2002).

Effect of process variable on rehydration ratio of freeze-thaw dehydrated garlic slices

The experimental values of rehydration during production of freeze-thaw dehydrated garlic slices by varying the process parameters is 1.107 to $2.912 \%$.

Table 3 shows that the effect of all process variables was significant at linear, quadratic and interaction level for rehydration ratio. The $\mathrm{R}^{2}$ value was found to be 0.9997 for rehydration ratio, which shows a good fit of model with the data.

The model $\mathrm{F}$ value of 8.90 for rehydration ratio implies that the model is significant $(\mathrm{P}<$
0.001). The $F$ value of lack of fit was nonsignificant which indicated that the developed model was adequate for predicting the rehydration ratio during the production freeze-thaw dehydrated garlic slices.

A second order polynomial equation eq. (4) was fitted with the experimental data. The regression equation describing the effects of process variables on rehydration ratio in terms of coded values of variable is given in Eq. (7).

$\mathrm{RR}=2.77-0.5038 \mathrm{x} 1-0.2144 x_{2}-2415 x_{2} x_{3}$

$-0.4843 x_{1}^{2}-0.3466 x_{2}^{2}-0.5301 x_{3}^{2}$

Coefficients of Eq. 7 were explained the effect of individual variables and their interactions on rehydration ratio. It was observed that the negative coefficient in case of first order term freezing temperature and thawing temperature indicated decrease in response with increase of these variables.

Effect of process variable on shrinkage ratio of freeze-thaw dehydrated garlic slices

The experimental values of shrinkage ratio during production of freeze-thaw dehydrated garlic slices by varying the process parameters is 0.451 to $0.622 \%$. Table 3 shows that the effect of all process variables was significant at linear, quadratic and interaction level for shrinkage ratio. The $\mathrm{R}^{2}$ value was found to be 0.9923 for shrinkage ratio, which shows a good fit of model with the data. The model $F$ value of 2.80 for shrinkage ratio implies that the model is significant $(\mathrm{P}<0.001)$. The $F$ value of lack of fit was non-significant which indicated that the developed model was adequate for predicting the shrinkage ratio during the production freeze-thaw dehydrated garlic slices.

A second order polynomial equation eq. (4) 
was fitted with the experimental data. The regression equation describing the effects of process variables on shrinkage ratio in terms of coded values of variable is given in Eq. (8). The data for shrinkage ratio were analysed by stepwise regression method where factors with F-values less than one were rejected as suggested by Snedecor and Cochran (1967).

$$
\begin{aligned}
& \mathrm{SR}=0.4822 x_{1}+0.0370 x_{2}+0.0289 x_{3} \\
& -0.0132 x_{1} x_{2}-0.0097 x_{1} x_{3}+0.02045 x_{2} x_{3}+0.0354 x_{1}^{2}+ \\
& 0.0172 x_{2}^{2}+0.0436 x_{3}^{2}
\end{aligned}
$$

Coefficients of Eq. 8 were explained the effect of individual variables and their interactions on rehydration ratio. It was observed that the positive coefficient in case of first order term freezing temperature, thawing temperature and thawing temperature revealed that shrinkage ratio increased with in response with increase of these variables. Interaction term showed negative effect on shrinkage ratio.

\section{Optimization of process for the production of freeze-thaw dehydrated garlic slices}

The criteria for constraint for optimization are given in Table 4. The constraints were set such that the selected variables (A, B and C) would be minimum of process parameters of experiment conducted.

The main criteria for constraints optimization were target value of colour (L-value) and hardness of 59.55 and 2398 g, maximum rehydration ratio and minimum shrinkage ratio of $2.854 \%$ and $0.455 \%$. Colour and hardness of 59.55 and $2398 \mathrm{~g}$ was taken as a target value on the basis of the preliminary experimental results of sensory data. Graphical multi-response optimization technique was adopted to determine the optimum conditions for the freeze-thaw dehydration of garlic slices.

\section{Validation of the model for production of freeze-thaw dehydrated garlic slices}

Freeze-thaw dehydration experiments were conducted at the optimum process conditions freezing temperature $\left(\mathrm{X}_{1}\right)=-25^{\circ} \mathrm{C}$, thawing temperature $\left(\mathrm{X}_{2}\right)=5^{\circ} \mathrm{C}$ and drying temperature $\left(\mathrm{X}_{3}\right)=60^{\circ} \mathrm{Cfor}$ testing the adequacy of model equations for predicting the response values. The observed experimental values (mean of 3 experiments) and values predicted by the equations of the model are presented in Table 5.

The experimental values were found to be very close to the predicted values for colour, hardness, rehydration ratio and shrinkage ratio with the value of $\mathrm{C} . \mathrm{V}$. as $3.85 \%, 5.23$ $\%, 4.29 \%$ and $1.26 \%$, respectively. The values of $\mathrm{CV}$ and closeness between experimental values and predicted values of the response parameters indicated the suitability of the corresponding models.

Table.1 Details of different treatments for production of freeze-thaw dehydrated garlic slices

\begin{tabular}{|l|c|c|c|c|}
\hline Parameters & Notations & \multicolumn{3}{|c|}{ Process variable coded } \\
\hline Freezing temperature $\left({ }^{\circ} \mathbf{C}\right)$ & F & -5 & -15 & -25 \\
\hline Thawing temperature $\left({ }^{\circ} \mathbf{C}\right)$ & T & 1 & 15 & 30 \\
\hline Drying temperature $\left({ }^{\circ} \mathbf{C}\right)$ & D & 50 & 60 & 70 \\
\hline
\end{tabular}


Table.2 Observed colour (L- value), hardness, rehydration ratio and shrinkage ratio under varying processing parameters

\begin{tabular}{|c|c|c|c|c|c|}
\hline $\begin{array}{c}\text { Sr. } \\
\text { No. }\end{array}$ & Treatments & $\begin{array}{c}\text { Colour } \\
\text { L- value }\end{array}$ & Hardness, g & $\begin{array}{c}\text { Rehydration } \\
\text { ratio }\end{array}$ & $\begin{array}{c}\text { Shrinkage } \\
\text { ratio }\end{array}$ \\
\hline 1 & $\mathrm{~F}_{3} \mathrm{~T}_{1} \mathrm{D}_{2}$ & 59.56 & 2384 & 2.912 & 0.451 \\
\hline 2 & $\mathrm{~F}_{1} \mathrm{~T}_{1} \mathrm{D}_{2}$ & 56.42 & 2512 & 1.39 & 0.587 \\
\hline 3 & $\mathrm{~F}_{3} \mathrm{~T}_{3} \mathrm{D}_{2}$ & 57.13 & 2510 & 2.33 & 0.51 \\
\hline 4 & $\mathrm{~F}_{1} \mathrm{~T}_{3} \mathrm{D}_{2}$ & 54.12 & 2756 & 1.107 & 0.591 \\
\hline 5 & $\mathrm{~F}_{3} \mathrm{~T}_{2} \mathrm{D}_{1}$ & 59.12 & 2451 & 2.16 & 0.508 \\
\hline 6 & $\mathrm{~F}_{1} \mathrm{~T}_{2} \mathrm{D}_{1}$ & 55.12 & 2512 & 1.334 & 0.568 \\
\hline 7 & $\mathrm{~F}_{3} \mathrm{~T}_{2} \mathrm{D}_{3}$ & 51.13 & 2610 & 2.004 & 0.572 \\
\hline 8 & $\mathrm{~F}_{1} \mathrm{~T}_{2} \mathrm{D}_{3}$ & 50.13 & 2680 & 1.535 & 0.593 \\
\hline 9 & $\mathrm{~F}_{2} \mathrm{~T}_{1} \mathrm{D}_{1}$ & 55.13 & 2512 & 2.061 & 0.505 \\
\hline 10 & $\mathrm{~F}_{2} \mathrm{~T}_{3} \mathrm{D}_{1}$ & 50.13 & 2634 & 2.112 & 0.548 \\
\hline 11 & $\mathrm{~F}_{2} \mathrm{~T}_{1} \mathrm{D}_{3}$ & 49.13 & 2714 & 2.142 & 0.497 \\
\hline 12 & $\mathrm{~F}_{2} \mathrm{~T}_{3} \mathrm{D}_{3}$ & 48.69 & 2798 & 1.241 & 0.622 \\
\hline 13 & $\mathrm{~F}_{2} \mathrm{~T}_{2} \mathrm{D}_{2}$ & 56.31 & 2453 & 2.963 & 0.492 \\
\hline 14 & $\mathrm{~F}_{2} \mathrm{~T}_{2} \mathrm{D}_{2}$ & 56.13 & 2463 & 2.854 & 0.451 \\
\hline 15 & $\mathrm{~F}_{2} \mathrm{~T}_{2} \mathrm{D}_{2}$ & 56.98 & 2489 & 2.456 & 0.459 \\
\hline 16 & $\mathrm{~F}_{2} \mathrm{~T}_{2} \mathrm{D}_{2}$ & 56.87 & 2412 & 2.874 & 0.453 \\
\hline 17 & $\mathrm{~F}_{2} \mathrm{~T}_{2} \mathrm{D}_{2}$ & 56 & 2439 & 2.716 & 0.551 \\
\hline
\end{tabular}

Where, Freezing temperature $(\mathrm{C})\left(\mathrm{F}_{1}=-5, \mathrm{~F}_{2}=-15\right.$ and $\left.\mathrm{F}_{3}=-25\right)$

Thawing temperature $\left({ }^{\circ} \mathrm{C}\right)\left(\mathrm{T}_{1}=1, \mathrm{~T}_{2}=15\right.$ and $\left.\mathrm{T}_{3}=30\right)$

Drying temperature garlic slices $\left({ }^{\circ} \mathrm{C}\right)\left(\mathrm{D}_{1}=50, \mathrm{D}_{2}=60\right.$ and $\left.\mathrm{D}_{3}=70\right)$

Table.3 Analysis of variance (ANOVA) for response surface quadratic model for production of freeze-thaw dehydrated garlic slices

\begin{tabular}{|c|c|c|c|c|c|c|c|c|c|}
\hline \multirow[t]{3}{*}{ Variable } & \multirow[t]{3}{*}{ DF } & \multicolumn{8}{|c|}{ F-values } \\
\hline & & \multicolumn{2}{|c|}{ Colour (L-value) } & \multicolumn{2}{|c|}{ Hardness, $g$} & \multicolumn{2}{|c|}{ Rehydration ratio (\%) } & \multicolumn{2}{|c|}{ Shrinkage ratio (\%) } \\
\hline & & SS & F-values & SS & F-values & SS & F-values & SS & F-values \\
\hline Model & 9 & 185.79 & $31.21 * * *$ & $2.398 \mathrm{E}+05$ & $13.36^{* *}$ & 5.76 & $8.90 * *$ & 0.0397 & $2.80 * *$ \\
\hline $\begin{array}{l}\text { F-Freezing } \\
\text { temperature }\end{array}$ & 1 & 15.52 & $23.46 * *$ & 32392.72 & $16.25^{*}$ & 2.03 & $28.22 * *$ & 0.0110 & $6.96^{*}$ \\
\hline $\begin{array}{l}\text { T-Thawing } \\
\text { temperature }\end{array}$ & 1 & 12.93 & 19.54 & 41472.00 & 20.81 & 0.3677 & $5.11 *$ & 0.0067 & 4.23 \\
\hline $\begin{array}{l}\text { D-Drying } \\
\text { temperature }\end{array}$ & 1 & 51.28 & $77.51 * * *$ & 59772.95 & $29.99 * * *$ & 0.0757 & 1.05 & 0.0031 & 1.98 \\
\hline FT & 1 & 0.0030 & 0.0046 & 3730.36 & 1.87 & 0.0188 & 0.2608 & 0.0007 & $0.4398 * *$ \\
\hline FD & 1 & 2.25 & 3.40 & 20.25 & 0.0102 & 0.0319 & 0.4430 & 0.0004 & 0.2414 \\
\hline TD & 1 & 5.42 & 8.19 & 348.13 & 0.1746 & 0.2333 & 3.24 & 0.0017 & 1.06 \\
\hline $\mathbf{F}^{2}$ & 1 & 12.56 & 18.99 & 150.32 & 0.0754 & 0.9876 & 13.73 & 0.0053 & 3.35 \\
\hline $\mathbf{T}^{2}$ & 1 & 7.49 & 11.32 & 36231.64 & 18.18 & 0.5042 & 7.01 & 0.0012 & $0.7861 * *$ \\
\hline $\mathrm{D}^{2}$ & 1 & 78.22 & $118.25^{* *}$ & 58652.21 & $29.42 * *$ & 1.18 & 16.45 & 0.0080 & $5.09 *$ \\
\hline Lack of fit & 3 & 3.85 & $6.57^{\mathrm{NS}}$ & 10696.76 & $4.38^{\mathrm{NS}}$ & 0.3468 & $2.95^{\mathrm{NS}}$ & 0.0038 & $0.7117^{\mathrm{NS}}$ \\
\hline $\mathbf{R}^{2}$ & & 0.9757 & & 0.9860 & & 0.9997 & & 0.9923 & \\
\hline
\end{tabular}

*** Significant at $0.0001, * *$ Significant at $0.001, *$ Significant at 0.05, NS - Non significant 
Table.4 Optimization criteria for different process variables and responses for production of Freeze-thaw dehydrated garlic slices

\begin{tabular}{|l|c|c|c|}
\hline Process variables & Goal & $\begin{array}{c}\text { Experimental } \\
\text { range }\end{array}$ & $\begin{array}{c}\text { Solutions } \\
\text { obtained }\end{array}$ \\
\hline $\begin{array}{l}\text { Freezing temperature, } \\
\text { oC }\end{array}$ & In range & -5 to -25 & -23.35 \\
\hline $\begin{array}{l}\text { Thawing temperature, } \\
\text { o C }\end{array}$ & In range & 1 to 30 & 5.29 \\
\hline Drying temperature, ${ }^{\mathbf{0}}$ C & In range & 50 to 70 & 58.41 \\
\hline Response variables & In range (55-60) & $48.65-59.56$ & 59.55 \\
\hline Colour (L-value) & In range $=(2385-2400)$ & $2384-2798$ & 2398 \\
\hline Hardness, g & Maximum & $1.107-2.912$ & 2.854 \\
\hline $\begin{array}{l}\text { Rehydration ratio, } \\
\text { percent }\end{array}$ & Minimum & $0.451-0.622$ & 0.455 \\
\hline Shrinkage ratio, percent & & &
\end{tabular}

Table.5 Predicted and experimental values of response variables of dehydrated garlic slice prepared at optimum process conditions

\begin{tabular}{|l|c|c|c|}
\hline \multicolumn{1}{|c|}{ Response } & $\begin{array}{c}\text { Predicted } \\
\text { Value }\end{array}$ & $\begin{array}{c}\text { Experimental value } \\
(\mathbf{\pm S D})\end{array}$ & C.V., \% \\
\hline Colour (L-value) & 59.55 & $59.71 \pm 0.113$ & 3.85 \\
\hline Hardness, g & 2398 & $2385 \pm 0.117$ & 5.23 \\
\hline $\begin{array}{l}\text { Rehydration ratio } \\
(\boldsymbol{\%})\end{array}$ & 2.854 & $2.650 \pm 0.112$ & 4.29 \\
\hline Shrinkage ratio $(\boldsymbol{\%})$ & 0.455 & $0.463 \pm 0.123$ & 1.26 \\
\hline
\end{tabular}

It can be concluded from the results of this investigation that freezing temperature, thawing temperature and drying temperature having significant effect on the quality characteristic of freeze-thaw dehydrated garlic slices. The regression equations obtained in this study can be used to predict the desired properties of the garlic slices.

The optimum conditions predicted based on numerical optimization were- $25^{\circ} \mathrm{C}$ freezing temperature, $5^{\circ} \mathrm{C}$ of thawing temperature and $60^{\circ} \mathrm{C}$ drying temperature for targeted colour (L-value 59.55) and hardness (2395 g). Maximum rehydration ratio $(2.854 \%)$ and minimum shrinkage ratio $(0.455 \%)$. The results of responses observed after confirmatory experiment were in good agreement with the predicted responses of the model.

\section{References}

Ambrose D.C.P. and Sreenarayanan V.V (1998) Studies on the dehydration of garlic. J. Food Sci Tech Mys. 35:242244.

AOAC (2000) Official methods of analysis of AOAC international. $19^{\text {th }}$ edn. Washington, D.C. 
Association of official analytical chemists.

Box G. E. and Behnken D. W. (1960) Some new three levels designs for the study of quantitative variables. Technometrics 2:455-75.

Gebreyohannes G. and Gebreyohannes M. (2013) Medicinal values of garlic: A review. Int J Medi Sci. 5(9):401-408.

Khodke Smita and Chattopadhyay P. K. (2002) Optimization of freeze thaw dehydrated instant potato cubes. In Proceedings: Food and Bioprocess Engineering. No $55 \mathrm{pp}$

Londhe V. P., Gaavasane A. T., Nipate S.S. Dandawane D. D. and Chaudhari P. D. (2011) Role of garlic (Allium sativum) in various disease: An overview. J Pharm Res Opinion. 1(4):129-134.

Nourian F., Ramaswamy H. S. and Kushalappa (2003) Kinetic changes in cooking quality of potatoes stored at different temperatures. Journal of Food Engg. 60:257-266

Prachayawarakorn D., Kaewnin N., Nanthakaranakule A., and Soponronnarit S. (2006) Effect of peeled and unpeeled garlic cloves on the changes of drying rate and quality. Dry Technol. 24(1):65-75.

Ranganna, S. (1995). Hand book of analysis and quality control for fruit and vegetable products. Tata MCG raw Hill Publs. Ltd., New Delhi (India).

\section{How to cite this article:}

Gajabe. M. H., S. U. Khodke and More. P. G. 2020. Optimization of process Parameter for the Production of Dehydrated Garlic Slices by using Freeze-Thaw Convective Drying Technique. Int.J.Curr.Microbiol.App.Sci. 9(02): 1820-1828. doi: https://doi.org/10.20546/ijcmas.2020.902.208 